WANL-TMI-766

EE-3220

August 12, 1963

\title{
LATERAL SUPPORT MACHINE SCREW TORQUE TEST
}

(WR 4i:41:26-8W)

by

L. E. Parsons

Engineering Mechanics

Distribution:
L. W. H. Esselman
Mr. H. F. Faught
Dr. W. H. Arnold, Jr.
Mr. H. S. McCreary, Jr.
Mr. J. Kenney, Jr.
Mr. D. Wiebe
Mr. B. C. Wells

Mr. C-K Kim

Mr. A. Selz

Mr. R. Saccocio

Mr. J. Fisch

Mr. L. Gesinski

Mr. E. Holt

File (5)

Library (2)

This report was prepared NOTICE

ponsored by the prepared as an account of work the United States United States Government. Neither Research and their and Administration, nor any of their contractors, subcontractors, or their employees, makes any, warranty, express or implied, or assumes any lability or responsibility for the accuracy, completenas or usefulness of any information apparatus, process disclosed, or represt or infringe privately or that its ase would

Approved by:

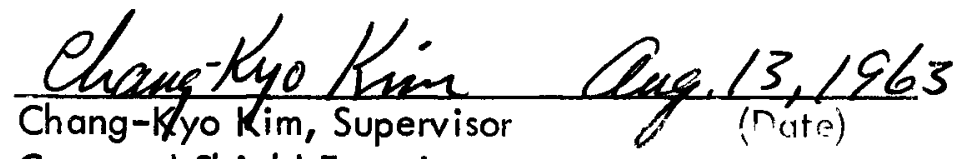

Core and Shield Experiments

Engineering Mechanics

INFORMATION CATEGORY

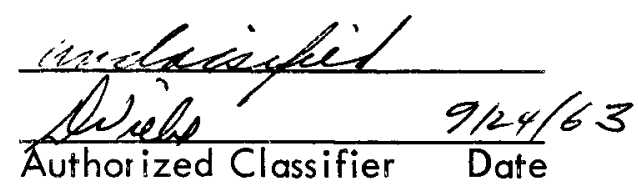

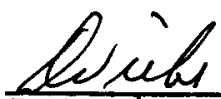

D. Wiebe, Manager

Engineering Mechanics

Experimental Engineering

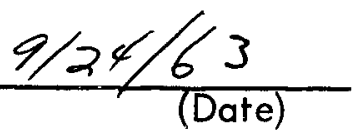

(Date) 


\section{DISCLAIMER}

This report was prepared as an account of work sponsored by an agency of the United States Government. Neither the United States Government nor any agency Thereof, nor any of their employees, makes any warranty, express or implied, or assumes any legal liability or responsibility for the accuracy, completeness, or usefulness of any information, apparatus, product, or process disclosed, or represents that its use would not infringe privately owned rights. Reference herein to any specific commercial product, process, or service by trade name, trademark, manufacturer, or otherwise does not necessarily constitute or imply its endorsement, recommendation, or favoring by the United States Government or any agency thereof. The views and opinions of authors expressed herein do not necessarily state or reflect those of the United States Government or any agency thereof. 


\section{DISCLAIMER}

Portions of this document may be illegible in electronic image products. Images are produced from the best available original document. 
WANL-TMI-766

EE-3220

\section{ABSTRACT}

The lateral support springs are fastened to the graphite barrel by means of an aluminum bracket and two 5/16-24 aluminum machine screws. Room temperature static tests were conducted to determine the torque that should be applied to these screws during reactor assembly. The maximum allowable torque the internal graphite threads will carry is approximately 60 inch-pounds. The recommended assembly torque is 30 to 40 inch-pounds.

Tests indicated that the quality of the bolt threads has a noticeable effect on the strength of this size internal graphite threads. 


\section{INTRODUCTION AND PURPOSE}

The NRX-Al Inner Reflector utilizes threaded holes in the Graphite Barrel to contain the lateral support spring reaction. The leaf-springs are contained by a spring bracket which is bolted to the graphite barrel with two fine thread 5/16 inch machine screws. The resultant strerigth of this subassembly can be affected by assembly torque-down of the screws beyond some stated value. The purpose of this test is to determine this value.

Tests were conducted to determine the maximum allowable preload torque and a recommended preload torque. A noticeable ditference in test data was observed from the preliminary strength data for zero preload :orque as reported in a letter to R. Saccocio (EE-3027) dated March 15, 1963 (see lables 11 and III. Tests were then conducted to determine the reasons for this discrepancy. Various possible reasons for this discrepancy are listed below:

1. Graphite Thread Quality - This is a known variable and is determined by visual inspection.

2. Different Parent Blocks - The specimens for this re.i were taken from a different parent block of HLM than those previously reported.

3. Test Setup - A different test rig was used for the preload tests than that used for the pievious zero preload tesis. This ir cluded a difference in the support seat diameter of the specimen.

4. Specimen Size - Previous specımens were $4^{\prime \prime} \times 4^{\prime \prime} \times 1^{\prime \prime}$ while those used in this test were $4^{\prime \prime} \times 4^{\prime \prime} \times 4$. Specime" size can rave an effect when dealing with brittle materials, although it is doubtful that this reason would cause such a discrepancy.

5. Assembly Error - This includes the possibility of instrumentation error and operator assembly errors (i.e., bolt assembled other than two diameters deep).

6. Screw Quality - Since the present test used the actual machine screws for the NRX-Al, this may cause a discrepancy from prior results which used a rod with threads cut by a die (due to the lack of 5/16-24 bolts at the time). A difference in screw material is another possible discrepanty. 


\section{TEST RESULTS}

In general, individual test results were within $\$ 10 \%$ of the averages for each group. Table I shows five values of preload torque which essentially stripped the graphite threads. Five values of 62 to 65 inch-pounds torque were measured. Note however, that in Table II, failure in one test initiated at $60 \mathrm{inch-pounds} \mathrm{torque.} \mathrm{Also}$ notice that one test was conducted at 70 inch-pounds preload which did not fail during torquing.

In Table II the results are listed for 10 inch-pound increments in preload torques. This test simulated its reactor counterpart except that the load was pure tension. This was done per Reactor Mechanical Design Section's request. In the reactor the screw carries a moment from the spring bracket, also. Five values were obtained at each preload torque with the averages given for the proportional limit and the ultimate load. The proportional limit was obtained from a chart which measured load versus relative movement between the bolt and the graphite block specimen. This value can be interpreted as the load at which initiation of failure of the graphite threads occurs. The ultimate load is the maximum load the threads carried before complete failure occurred. Although results would tend to indicate an opt imum preload torque of $\sim 40$ inch-pounds, the range of test results is comparable at each torque range (10002000 pounds). Since the maximum allowable torque is 60 inch-pounds, a design preload torque of 30-40 inch-pounds is a good value. Actually there is no 'optimum' preload torque between zero and maximum preload torque.

This is because we are dealing with internal threads where the load is the sum of two components (see sketch on next page). The first is the preload from the torque which is relieved as the second load, the axial load due to the bolt loading mechanism, increases. The resultant force (net sum of the two) increases as the preload is decreased. The preload on the graphite threads must be overcome before failure of the threads occurs, otherwise the threads would have failed during torque-down. Hence, the resulfant net force on the threads at failure is due to the axial load of the tensile machine only. At failure the preload torque has no further effect on the strength of the graphite threads. 


\section{TEST SETUP}

The test specimens were 4 inch lengths of $4 " \times 4$ " extruded HLM graphite. The 4 sides were drilled providing 4 holes perpendicular to the grain. The holes were hand tapped about 1 inch deep. Machine screws furnished by the Reactor Mechanical Design Section were used with a resultant two diameters engagement. The torque was measured by means of a torque screw driver. The load was measured by the Wiedemam-Baldwin Tensile Machine in Building 8 . Chart records of test results were obtained also.

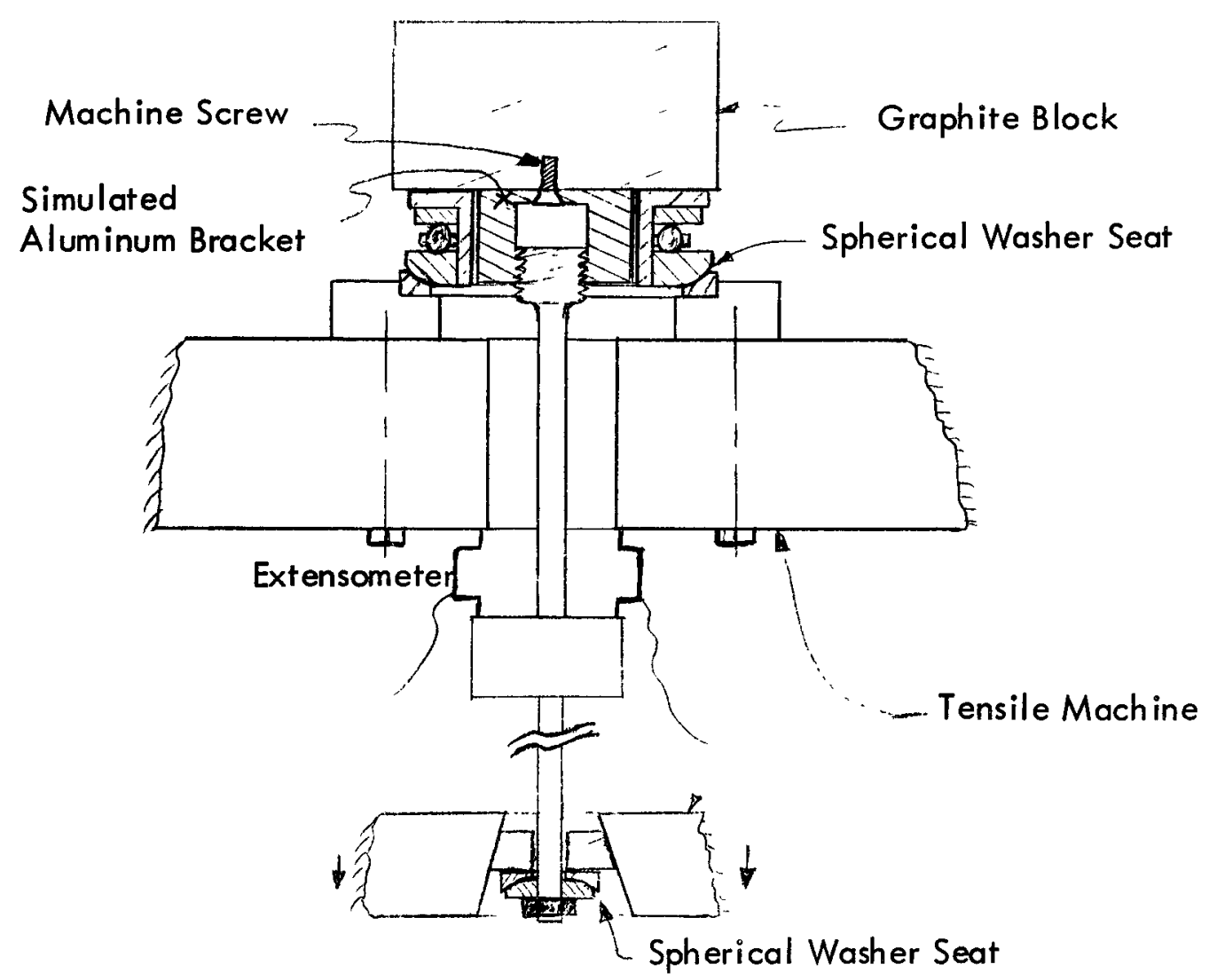

TEST SETUP 
WANL-TMI-766

EE-3220

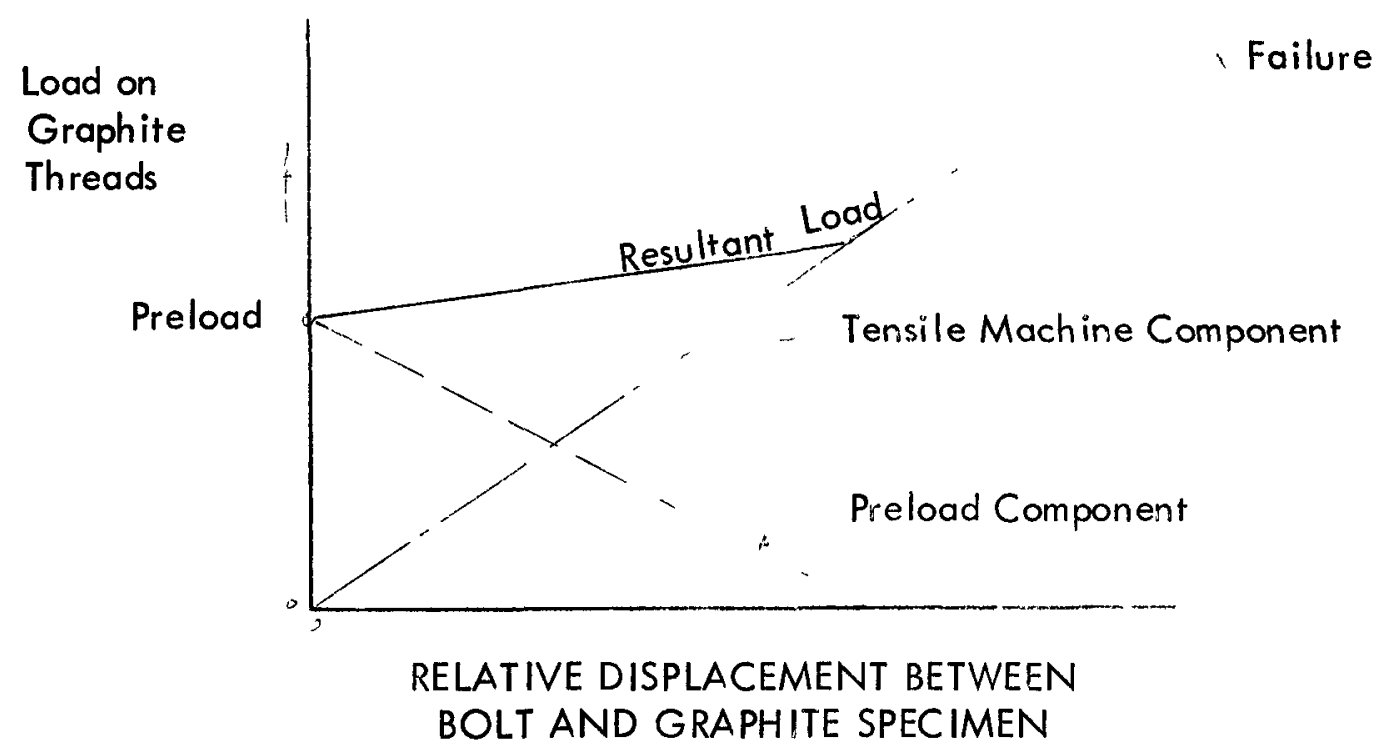

Table IV lists the test results obtained to discover the reason for the discrepancy between Table II and Table III, which were results reported March 15, 1963. The values in Table III are roughly $70 \%$ of those in Table 11 . Of the suggested sources of error given in the introduction, (1) and (5) were eliminated on the first test. Subsequent tests using various rigs, specimen sizes, and different bolts determined that the bolt was the variable involved. Further tests were conducted which determined that the quality of the bolt threads was the factor and not the bolt material. The effect of the quality of the bolt threads can be observed by scanning Table IV. Note that Table III values were obtained with a steel rod of poor quality threads made by a thread cutting die also. Note that the results of various commercial 5/16-24 bolts are still somewhat below those of the aluminum lateral support screws. Most of these tests were conducted with the hole parallel to the grain in Table IV while all results in Tables I, 11, and III are for the hole perpendicular to the grain. However, for HLM (H4LM) the strength values are not very different with the grain as across the grain.

Reports pertaining to graph ite threads pcinted out the importance of the qual ity of the graphite threads. It may now be added that the bolt thread quality (smoothness, percentage threads, etc.) is of great importance where the failure mode is 
WANL-TMI-766

$\mathrm{EE}-3220$

not by removal of graphite cone (see WANL-TMI-376). The failure mode is dependent on many things, including specimen size, depth of thread engagement, size of thread, type of graphite, and type of thread (also see WANL-TMI-540). Often sizes less than 1/2 inch tend to fail in the threads as shown by previous test data. 


\section{CONCLUSIONS}

From Table I it may be concluded that the maximum allowable preload torque for the lateral support machine screws is 60 inch-pounds. Table II illustrates a preload torque of approximately half that as a working value. That is, a value 30 to 40 inch-pounds provides strength yet is safely below the pullout torque value.

Of the six suggested sources of the discrepancy between Table II and Table III, the data of Table IV eliminated all but the effect of the quality of the screw threads. It has been previously reported (WANL-TMI-376) that bolt quality is insignificant when the failure mode is the removal of a conical section of graphite about the threads. However, for fine threads less than $1 / 2$ inch size, the failure mode is generally partial thread shear-partial removal of material (see WANL-TMI-376). The screw material was not found to be a factor. It is concluded that the quality of the bolt threads can have a significant effect on the results when the failure mode is the graphite threads. 
TABLE I

MAXIMUM PRELOAD TOROUE TEST

VALUES FOR THE NRX-AI INNER

REFLECTOR GRAPHITE THREADS WITH

THE LATERAL SUPPORT BRACKET

MACHINE SCREW AN507DD524-14

Preload Torque

63 in-lb

63 in-lb

62 in -16

65 in-lb

63 in- Ib
Failure Of

Graphite Threads

Graphite Threads

Graphite Threads

Graphite Trireads

Graphite Threads

Maximum Allowable Preload Torque $\sim 60{ }^{i} n-1 b$. 
WANL-TMI-766

$E E-3220$

TABLE $\|$

STRENGTH OF UNF 5/16-24 INTERNAL GRAPHITE THREADS VS. PRELOAD TORQUE FOR HLM GRAPHITETHREADED HOLE PERPENDICULAR TO THE GRAIN 5/8 INCH THREAD ENGAGEMENT - AN507DD524-14 ALUMINUM BOLT

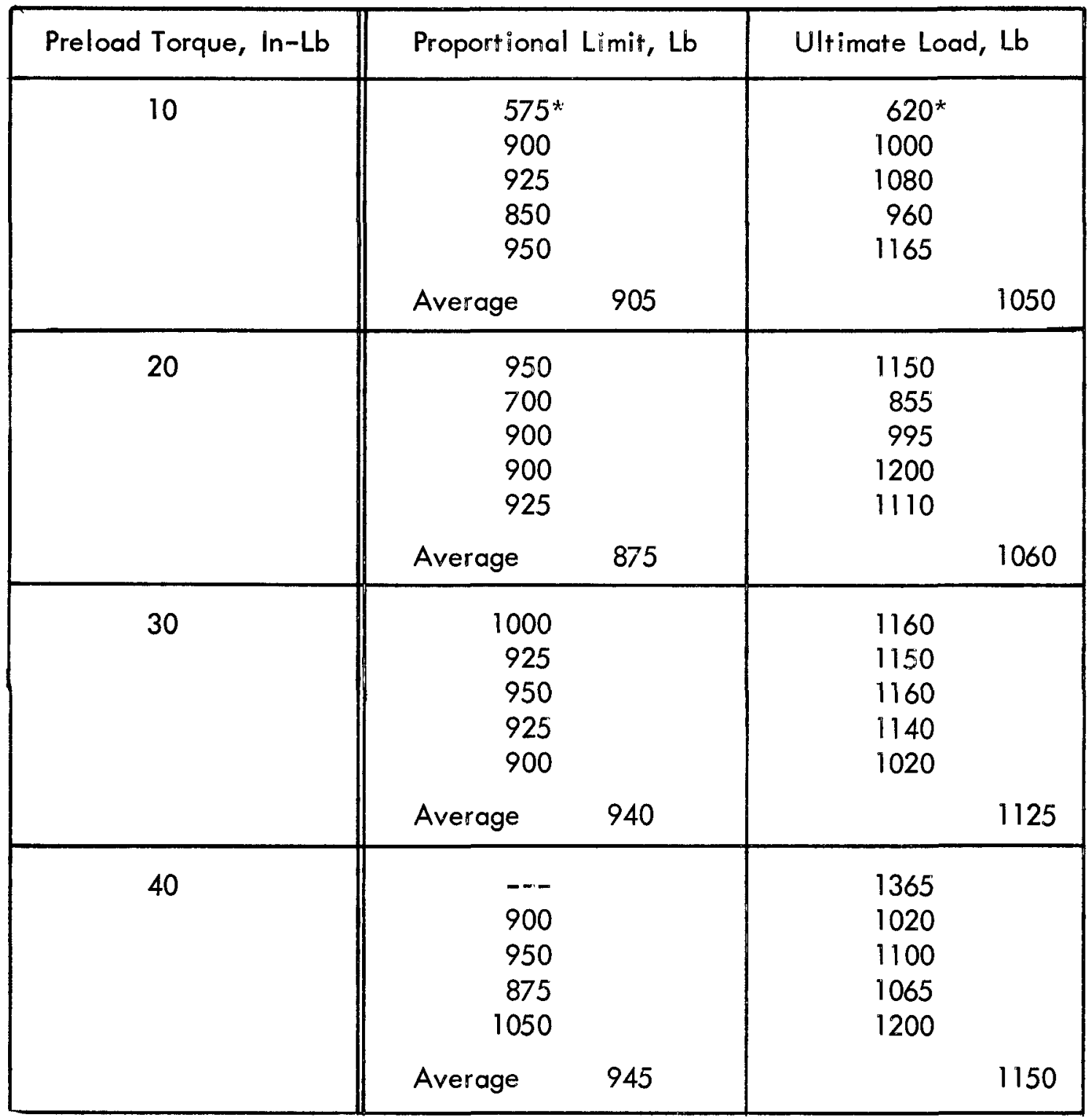

* Depth of Engagement was not 5/8 inch. 
TABLE II (Continued)

WANL-TMI-766

EE-3220

\begin{tabular}{|c|c|c|c|}
\hline Preload Torque, In-Lb & Proportic & nit, Lb & Ultimate Load, Lb \\
\hline \multirow[t]{2}{*}{50} & & & \multirow[t]{2}{*}{$\begin{array}{l}1060 \\
1220 \\
1170 \\
1080 \\
1080\end{array}$} \\
\hline & Average & 930 & \\
\hline \multirow[t]{2}{*}{60} & \multicolumn{2}{|c|}{$\begin{array}{l}900 \\
960 \\
930 \\
940 \\
600^{* *}\end{array}$} & $\begin{array}{l}1055 \\
1200 \\
1125 \\
1100 \\
650^{* *}\end{array}$ \\
\hline & Average & 930 & 1120 \\
\hline 70 & & & 1060 \\
\hline
\end{tabular}

* Partial Failure Occurred During Torque-Down.

$-10-$ 
WANL-TMI-766

EE-3220

TABLE II!

PRELIMINARY RESULTS OF THE STRENGTH

OF UNF 5/16-24 INTERNAL GRAPHITE

THREADS - HLM GRAPHITE - THREADED

HOLE PERPENDICULAR TO THE GRAIN -

2 DIAMETERS (5/8 INCH) BOLT ENGAGEMENT *

Proportional Limit

620

600

580

560
Ultimare Load

800

810

780

755

Average

590

790

*From letter to R. Saccocio (EE-3027) dated March 15, 1963. 
STRENGTH OF UNF 5/16-24 INTERNAL GRAPHITE THREADS FOR VARIOUS BOLTS - HLM GRAPHITE $5 / 8$ INCH DEPTH THREAD ENGAGEMENT

\begin{tabular}{|c|c|c|c|c|}
\hline Bolt & Description of Bolt Threads & $\begin{array}{l}\text { Proportional Limit } \\
\text { It }\end{array}$ & $\begin{array}{c}\text { Ultimate Load } \\
\text { Ib }\end{array}$ & $\begin{array}{l}\text { Direction of } \\
\text { Hole with Re- } \\
\text { spect to Grain }\end{array}$ \\
\hline Steel Rod & $\begin{array}{l}\text { Threads made with Die } \\
\text { Poor Qual ity }\end{array}$ & $\begin{array}{c}575 \\
- \\
600 \\
650\end{array}$ & $\begin{array}{l}795 \\
830 \\
828 \\
900\end{array}$ & $\begin{array}{c}\text { Parallel } \\
\text { " } \\
\text { " } \\
\text { " }\end{array}$ \\
\hline Steel Rod & $\begin{array}{c}\text { Threads made with Die } \\
\text { Fair Quality }\end{array}$ & $\begin{array}{l}760 \\
700\end{array}$ & $\begin{array}{l}880 \\
835\end{array}$ & $\begin{array}{c}\text { Perpendicular } \\
\text { " }\end{array}$ \\
\hline Aluminum & $\begin{array}{l}\text { Threads made with Die } \\
\text { Poor Quality }\end{array}$ & $\begin{array}{l}600 \\
600 \\
630\end{array}$ & $\begin{array}{l}660 \\
705 \\
707\end{array}$ & $\begin{array}{c}\text { Parallel } \\
11 \\
11\end{array}$ \\
\hline $\begin{array}{l}\text { Aluminum } \\
\text { Screw }\end{array}$ & $\begin{array}{l}\text { Threads made with Die } \\
\text { Good Guality }\end{array}$ & $\begin{array}{l}850 \\
800\end{array}$ & $\begin{array}{l}980 \\
913\end{array}$ & $\underset{" \text { Parallel }}{ }$ \\
\hline Brass Screw & $\begin{array}{c}\text { Threads made with Die } \\
\text { Good Quality }\end{array}$ & $\begin{array}{l}800 \\
800\end{array}$ & $\begin{array}{l}906 \\
955\end{array}$ & Parallel \\
\hline Allen Screw & $\begin{array}{l}\text { Commercial Threads } \\
\text { Good Quality }\end{array}$ & $\begin{array}{l}900 \\
900\end{array}$ & $\begin{array}{r}950 \\
1010 \\
\end{array}$ & $\underset{11}{\text { Parallel }}$ \\
\hline $\begin{array}{c}\text { Standard } \\
\text { Bolt }\end{array}$ & $\begin{array}{l}\text { Commercial Threads } \\
\text { Good Quality }\end{array}$ & $\begin{array}{l}900 \\
870\end{array}$ & $\begin{array}{r}1017 \\
943\end{array}$ & $\begin{array}{l}\text { Parallel } \\
\|\end{array}$ \\
\hline $\begin{array}{c}\text { Standard } \\
\text { Bolt }\end{array}$ & $\begin{array}{l}\text { Commercial Threads } \\
\text { Fair Quality }\end{array}$ & 810 & $\begin{array}{l}867 \\
923\end{array}$ & $\underset{1}{\text { Perpendicular }}$ \\
\hline $\begin{array}{c}\text { Reactor } \\
\text { Screws } \\
\text { (Aluminum) }\end{array}$ & $\begin{array}{l}\text { Standard Threads } \\
\text { Very Good Quality }\end{array}$ & $\begin{array}{l}900 \\
940\end{array}$ & $\begin{array}{l}1117 \\
1163\end{array}$ & $\begin{array}{c}\text { Parallel } \\
\text { " }\end{array}$ \\
\hline
\end{tabular}

